\title{
Classification and Characterization of Soils of Eturunagaram Division of Warangal District in Telangana State
}

\author{
E. Narsaiah ${ }^{1 *}$, T. Ramprakash ${ }^{1}$, M. Chandinipatnaik ${ }^{1}$, \\ D. Vishnuvardhan Reddy ${ }^{2}$ and G. Bhupal Raj ${ }^{1}$ \\ ${ }^{1}$ Department of Soil Science and Agricultural Chemistry, ${ }^{2}$ Department of Crop Physiology, \\ Professor Jayashankar Telangana State Agricultural University, \\ Rajendranagar, Hyderabad-500030, Telangana, India \\ *Corresponding author
}

\section{A B S T R A C T}

Six typical pedons from Eturunagaram division of warangal district were studied for physical, physico-chemical and chemical properties of the area. The soils were shallow to

\section{Keywords}

Characterization, Nutrient status, Classification, Soils and Physical properties

Article Info

Accepted: 04 May 2018 Available Online: 10 June 2018 very deep, dark yellowish brown to reddish brown in colour, sand to clay in texture and had varied structure including single grain, granular, sub-angular blocky and angular blocky. The clay content in soils varied from 10.5 to 62.2 per cent. The clay content increased with depth in all pedons. Silt fraction in the soils 5.0 to 28.3 per cent. The sand content in the soils under investigation varied from 15.2 to 84.5 percent. Most of the pedons exhibited more or less an increasing trend in bulk density with depth. These soils were near slightly acidic to moderate alkaline in reaction, non-saline and low to medium in organic carbon. The CEC varied from 4.8 to $49.4 \mathrm{cmol}\left(\mathrm{p}^{+}\right) \mathrm{kg}^{-1}$ soil and dominated by $\mathrm{Ca}^{+2}$ followed by $\mathrm{Mg}^{+2}, \mathrm{Na}^{+}$and $\mathrm{K}^{+}$. The soils were low to medium in available nitrogen, low to high in available phosphorus and potassium. Available zinc was deficient to sufficient in all the horizon. The soils were sufficient in available iron, copper and manganese. The soils were classified as Typic Rhodustalfs, Typic Haplustalfs, Typic Haplusterts, Lithic Ustorthents and Vertic Haplustept.

\section{Introduction}

Soil is a component of the lithosphere and biosphere system. It is a vital natural resource on whose proper use depends on the supporting life systems and socio- economic development. The per capita cultivable land has been declining from 0.32 ha through 0.14 to less than 0.1 ha by 2020 . The soil characterization determines the soil's individual inherent potentials and constraints for crop production besides giving detailed information about the different soil properties. Characterization and systematic classification of dominant soil groups is an essential tool and a pre-requisite for soil fertility evaluation and efficient soil-fertilizer-water management practices and thus crop management. The newly formed Telangana state has variable types of soils. Any progress and development 
in agriculture depends largely on soil resources. Maintaining soil in the state of high productivity on sustainable basis is important for meeting basic needs of the people. Systematic study of soils is important for scientific utilization of these soils and land resources.

\section{Materials and Methods}

The pedons from the study area in eturunagaram division of warangal district, lies in Central Telangana Zone in Telangana state which lies between $18^{\circ} 12^{\prime} \& 18^{\circ} 20^{\prime}$ North latitude and $79^{\circ} 36^{\prime} \& 80^{\circ} 07^{\prime}$ East longitude. The study area is characterised by semi arid climatic condition, with the average rainfall of $803.2 \mathrm{~mm}$ (decennial average of 2004-13) of which $90.11 \%$ is received during southwest monsoon, $4.80 \%$ during northeast monsoon and $5.08 \%$ during summer season. Mean monthly rainfall is highest in the month of July month $(214.4 \mathrm{~mm})$ followed by September $(177.5 \mathrm{~mm})$, August $(164.1 \mathrm{~mm})$ months. Annual mean maximum and minimum temperatures of the district are $32.44{ }^{\circ} \mathrm{C}$ and $23.31{ }^{\circ} \mathrm{C}$ respectively. The maximum and minimum mean monthly temperature ranges from $17.0^{\circ} \mathrm{C}$ to $40.8^{\circ} \mathrm{C}$. The mean minimum temperature is recorded during December $\left(17.0^{\circ} \mathrm{C}\right)$ and maximum in May $\left(40.8^{\circ} \mathrm{C}\right)$. Mean annual air temperature of the district is $27.78{ }^{\circ} \mathrm{C}$. Therefore, the temperature regime of the study area was classified as isohyperthermic. Natural vegetation comprises of Ficus spp, Tamarind (Tamarindus indica), neem (Ajadiracchta indica), Prosopis and ber (Zizyphus jujube) are predominated trees in the study area.

\section{Results and Discussion}

\section{Soil morphology}

The soil morphological description of the study area will be presented in the table 2 .The depth of different pedons of study area of Eturnagaram division of Warangal district varied from $8 \mathrm{~cm}$ to $130+\mathrm{cm}$ and found to have moderately deep to very deep solum. The highest depth of horizon was found in pedon 3 of Mangapet BSS3 horizon and the lowest depth was observed the horizon of pedon 4 horizon of AP. Pedon 4 and 5 were moderately deep whereas pedons 1, 2, 3 and 6 were deep. Nasre et al., (2013) noticed that soil depth is related to slope and degree of soil erosion. It was noticed that, soils developed on plateau top, escarpments, isolated hillocks and foot slopes were shallow and soils developed on undulating lands, alluvial plains and valleys were deep.

The colour of the soil pedons of Eturnagaram division of Warangal district were varied from strong brown to gray colour. Whereas hue in the range of 2.5 YR 5 YR,7.5 YR, value of 3 to 5 and chroma in the range of 2 to 6 respectively. Occurrence of iron oxides at various hydrated forms might have resulted in dark brown colour to the soils (Ramprakash and Seshagiri Rao, 2002). The texture of the pedons of study area was varied from sand to clay. The clay content in all the pedons were increased with increase in depth. Ramprakash and Seshagiri Rao (2002) observed that translocation of finer particles to lower horizons in coarse textured soils derived from resistant parent material could have resulted relatively finer texture in lower horizons. The structure of the soil pedons size of aggregate was medium, grade was week to strong, the type of aggregate was granular, sub-angular blocky to angular blocky. The pedons in the study area had single grain, sub-angular blocky and angular blocky structure. The blocky structures i.e., sub-angular and angular blocky were attributed to the presence of higher quantities of clay fractions. Similar observations were reported by Meena et al., (2012) in Malwa plateau of Banswara district in Rajasthan. 
The consistence of the soil pedons of eturnagaram division pedons 1 to 6 varied from slightly hard to very hard, loose to very firm and nonsticky to non-plastic and very stick to very plastic, whereas in the pedon 1,2 , $3,4,5$ were nonsticky to non-plastic and slightly sticky to slightly plastic in dry, moist and wet condition respectively. Sticky and plastic to very sticky and very plastic, firm to very firm and slightly hard to very hard consistence in wet, moist and dry conditions, respectively might be due to high clay content of the soils. Similar observations were also made by Leelavathi et al., (2009) in soils of Yerpedu mandal of Chittoor district in Andhra Pradesh.

The detailed Physical properties of the study area of eturnagaram division of Warangal district presented in table 3. The sand percentage of the pedons varied from 15.2 to 84.5 per cent The highest sand percentage was found in pedon 1 ( 84.5 per cent) whereas the lowest sand percentage was observed in pedon (15.2 per cent) horizon of (BW2). Higher sand content in these surface soils could be attributed loss of finer fractions of soils due to erosion, movement of clay to deeper horizons due illuviation and more active chemical weathering in the lower horizons due to better availability of moisture. Similar findings were also reported by Basavaraju et al., (2005)

The silt content varied from 5.0 to 28.3 per cent. The highest silt percentage was observed in pedon 6 of BW1 and lowest percentage of silt was observed in the pedon 5.0 percent. This might be due to variation in weathering of parent material or in situ formation. These results were in agreement with the findings of Satish Kumar and Naidu (2012a).

The clay content varied from 10.5 to 62.2 per cent. The highest the clay percent was recorded in the pedon 3 horizon of BSS2 (62.25 per cent) and lowest clay percentage was recorded in the pedon 1 of the AP horizon (10.5 percent). Increase in clay content with depth might be due to more intensive chemical weathering at deeper layer and eluviation of finer particles from surface horizon leaving behind coarse particles in surface layers. The enrichment of clay in Bw and Bss horizons of pedons 3 and 6 was primarily due to in situ weathering of parent material. Sharma et al., (2004) observed an increase in clay content in sub-surface horizons as compared to surface horizons in soils of Neogal watershed in north-west Himalayas. The increase in clay content in the $\mathrm{Bt}$ horizon in the pedons 1,2 and 5 is mainly due illuviation of the clay form the upper horizons. Similar enrichment Bt horizons with the clay content was reported by Ramprakash and Rao (2002) in Krishna district of Andhra Pradesh.

The bulk density of different pedons varied from $1.38 \mathrm{Mg} \mathrm{m}^{3}$ to $1.85 \mathrm{Mg} \mathrm{m}^{-3}$. The higher bulk density values in some pedons may be due to high clay content resulting in greater compaction in swelling clay soils. Similar results were reported by Ashokkumar and Jagdish Prasad (2010) who reported higher bulk density values in the soils of Ahmadnagar district of Maharashtra.

The particle density of different pedons varied from 2.55 to $2.65 \mathrm{Mg} \mathrm{m}^{-3}$. Not much variation in the particle density was recorded among different pedons. No regular increasing or decreasing trend was recorded in particle density in any of the pedons studies in the Warangal district.

The saturated hydraulic conductivity was ranged from $0.21 \mathrm{~cm} \mathrm{hr}^{-1}$ to $18.21 \mathrm{~cm} \mathrm{hr}^{-1}$. The hydraulic conductivity was recorded in the pedon 4 horizon of AP and lowest value of hydraulic conductivity. In all the pedons hydraulic conductivity decreased with increasing depth of the soil. Similar results were earlier reported by Ramprakash and 
Seshagiri Rao (2002) in Vertisols and Alfisols of Krishna district. Increasing compaction of soil with the depth resulting increasing bulk density, decreasing pore density might have resulted in reduction of the hydraulic conductivity with depth in all the studies pedons.

Available water content in the study area ranged from 1.7 per cent to 15.7 per cent. The highest AWC was observed in BSS3 horizon of pedon 3. While the lowest value of Available water content is 1.7 per cent was observed in AP horizon of pedon 2. These differences in water holding capacity were due to variation in the depth, clay, silt and organic carbon content of the pedons. These results match with those of Thangasamy et al., (2005) in soils of Sivagiri micro-watershed in Chittoor district of Andhra Pradesh.

The soil reaction of the study area was ranged from 6.3 to 8.8 i.e., slightly acidic to strongly alkaline in reaction. The highest value of $\mathrm{pH}$ was observed in pedon 6 AP horizon and while the lowest $\mathrm{pH}$ was found in pedon 1 horizon of AP horizon. This wide variation in
$\mathrm{pH}$ of soils was attributed to the nature of the parent material, leaching and presence of calcium carbonate and exchangeable sodium. Similar results were observed by Arun Kumar et al., (2002). Furthermore, the soil reaction in these soils varied from near neutral to very strongly alkaline. The near neutral to very strongly alkaline $\mathrm{pH}$ may be attributed to the reaction of applied fertilizer material with soil colloids, which resulted in the retention of basic cations on the exchange complex of the soil.

The electrical conductivity ranged from 0.12 to $1.12 \mathrm{dSm}^{-1}$. The highest value of $1.12 \mathrm{dSm}^{-1}$ was recorded in $\mathrm{BW}_{2}$ horizon of pedon 6 and the lowest electrical conductivity was observed in horizon of $\mathrm{Bt} 3$ of pedon 5 indicating non-saline in nature. The results in the present study indicate the non-saline nature of soils. The lower electrical conductivity in soils was due to excess leaching of salts and due to free drainage conditions which favoured the removal of released bases by percolating and drainage water. Similar results were observed by Ramprasad et al., (2013).

Table.1 Landscape characteristics of pedons:

\begin{tabular}{|c|c|c|c|c|c|c|}
\hline Pedon & Location & $\begin{array}{c}\text { Elevation above } \\
\text { mean sea level }(\mathrm{m})\end{array}$ & Physiography & $\begin{array}{l}\text { Slope } \\
(\%)\end{array}$ & Drainage & $\begin{array}{c}\text { Parent } \\
\text { material }\end{array}$ \\
\hline 1 & Ramagundam & $\begin{array}{l}18^{0} 19^{`} 15.73 ” \mathrm{~N} \\
80^{0} 27^{\circ} 24.68^{\prime \prime} \mathrm{E}\end{array}$ & Rolling topography & $3-8 \%$ & Well drained & $\begin{array}{l}\text { Granite } \\
\text { gneiss }\end{array}$ \\
\hline 2 & Eturnagaram & $\begin{array}{l}18^{0} 20^{`} 08.10^{\prime \prime} \mathrm{N} \\
79^{0} 36^{\circ} 10.72^{\prime} \mathrm{E}\end{array}$ & $\begin{array}{c}\text { Undulating inter } \\
\text { flares with isolated } \\
\text { mounds }\end{array}$ & $3-8 \%$ & $\begin{array}{l}\text { Excessively } \\
\text { drained }\end{array}$ & $\begin{array}{l}\text { Granite } \\
\text { gneiss }\end{array}$ \\
\hline 3 & Mangapet & $\begin{array}{l}18^{0} 14^{\prime} 59.14^{\prime \prime} \mathrm{N} \\
80^{\circ} 31^{\prime} 21.97 ” \mathrm{E}\end{array}$ & $\begin{array}{l}\text { Very gently sloping } \\
\text { uplands }\end{array}$ & $1-3 \%$ & $\begin{array}{c}\text { Imperfectly } \\
\text { drained with } \\
\text { low } \\
\text { permeability }\end{array}$ & $\begin{array}{l}\text { Weathered } \\
\text { basalt }\end{array}$ \\
\hline 4 & Narlapur & $\begin{array}{l}18^{0} 18^{`} 39.41 ” \mathrm{~N} \\
80^{0} 12^{\prime} 22.09^{\prime \prime} \mathrm{E}\end{array}$ & $\begin{array}{l}\text { Undulating inter } \\
\text { flures }\end{array}$ & $3-8 \%$ & $\begin{array}{l}\text { Excessively } \\
\text { drained }\end{array}$ & Granite \\
\hline 5 & Medaram & $\begin{array}{l}18^{0} 19^{\prime} 28.01 " \mathrm{~N} \\
80^{0} 14^{\prime} 36.17^{\prime \prime} \mathrm{E}\end{array}$ & $\begin{array}{l}\text { Undulating inter } \\
\text { flures }\end{array}$ & $3-8 \%$ & Well drained & $\begin{array}{l}\text { Granite } \\
\text { gneiss }\end{array}$ \\
\hline$\overline{6}$ & Govindaraopet & $\begin{array}{l}18^{0} 12^{`} 03.10^{\prime \prime} \mathrm{N} \\
80^{\circ} 07^{\circ} 45.35^{\prime} \mathrm{E}\end{array}$ & Valley & $0-1 \%$ & $\begin{array}{l}\text { Poorly drained } \\
\text { with moderate } \\
\text { permeability }\end{array}$ & $\begin{array}{l}\text { Alluvium - } \\
\text { colluviums of } \\
\text { lime stone }\end{array}$ \\
\hline
\end{tabular}


Table.2 Morphological description of the study area of Eturnagaram division of Warangal district in Telangana State

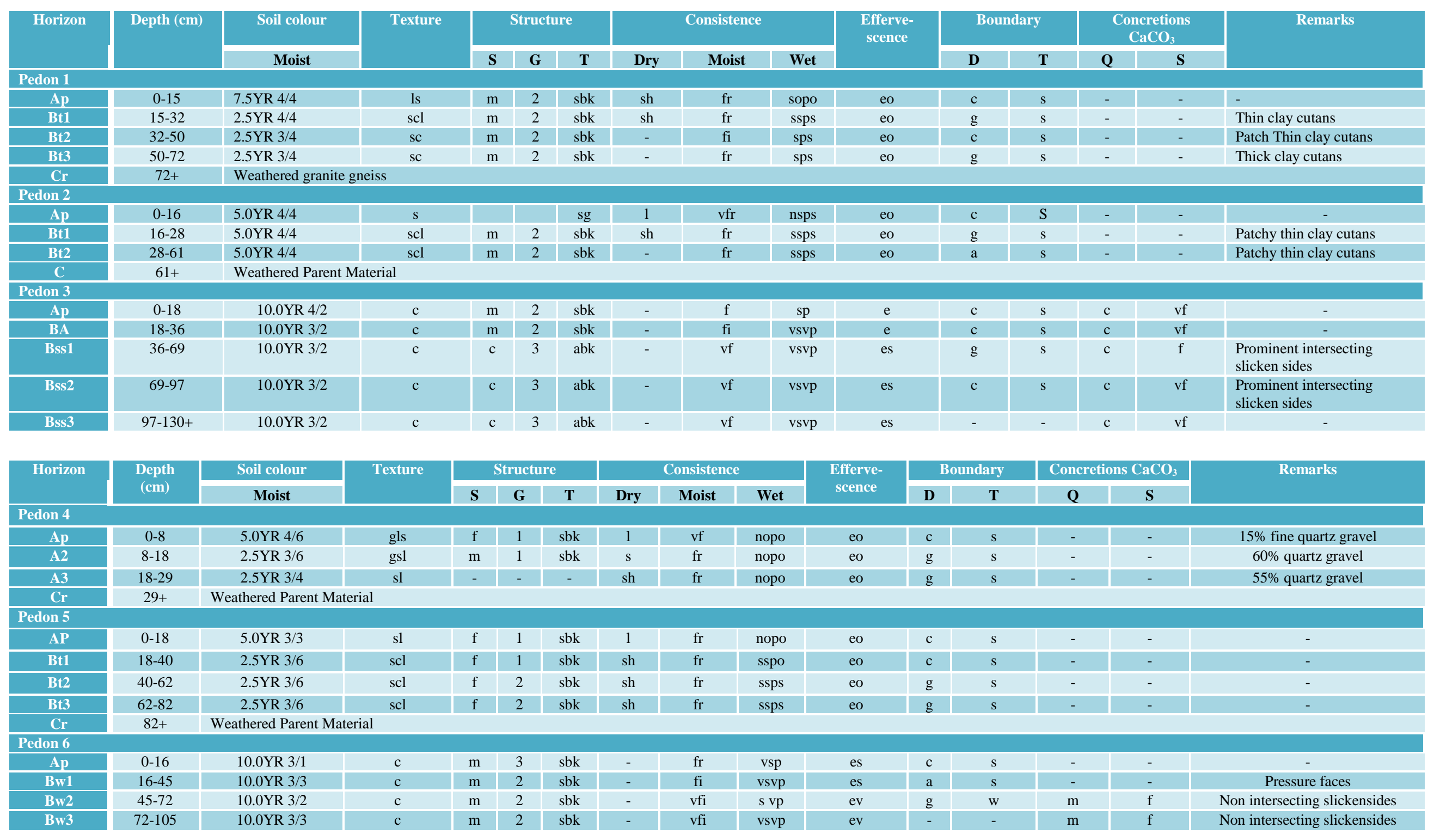


Int.J.Curr.Microbiol.App.Sci (2018) 7(6): 582-594

Table.3 Physical properties of the study area

\begin{tabular}{|c|c|c|c|c|c|c|c|c|c|c|}
\hline \multirow{2}{*}{$\begin{array}{l}\text { Pedon } \\
\text { No. \& } \\
\text { Horizon }\end{array}$} & \multirow[t]{2}{*}{$\begin{array}{l}\text { Depth } \\
(\mathrm{cm})\end{array}$} & \multirow{2}{*}{$\begin{array}{l}\text { Sand } \\
(\%) \\
(0.2- \\
0.05 \\
\mathrm{~mm})\end{array}$} & \multirow{2}{*}{$\begin{array}{l}\text { Silt } \\
(\%) \\
(0.5 \\
\mathbf{m m})\end{array}$} & \multirow{2}{*}{$\begin{array}{c}\text { Clay } \\
(\%) \\
(< \\
0.002 \\
\text { mm) }\end{array}$} & \multirow{2}{*}{$\begin{array}{c}\text { Bulk } \\
\text { density } \\
(\mathrm{Mg} \\
\left.\mathbf{m}^{-3}\right)\end{array}$} & \multirow{2}{*}{$\begin{array}{l}\text { Particle } \\
\text { density } \\
\left(\mathbf{M g ~ m}^{-}\right. \\
\mathbf{3})\end{array}$} & \multirow{2}{*}{$\begin{array}{l}\text { Hydraulic } \\
\text { Conductivity } \\
\left(\mathrm{cm} \mathrm{hr}^{-1}\right)\end{array}$} & \multicolumn{2}{|c|}{$\begin{array}{c}\text { Water } \\
\text { retention }\end{array}$} & \multirow{2}{*}{$\begin{array}{c}\text { Available } \\
\text { Water } \\
\text { Content } \\
(\%)\end{array}$} \\
\hline & & & & & & & & $\begin{array}{c}33 \\
\mathrm{Kpa}\end{array}$ & $\begin{array}{l}1500 \\
\text { Kpa }\end{array}$ & \\
\hline \multicolumn{11}{|l|}{ P1 } \\
\hline $\mathbf{A p}$ & $0-15$ & 84.5 & 5 & 10.5 & 1.56 & 2.65 & 14.25 & 6.2 & 3.1 & 3.1 \\
\hline Bt1 & $15-32$ & 70.9 & 6.5 & 22.6 & 1.59 & 2.53 & 8.6 & 12.9 & 6.5 & 6.4 \\
\hline Bt2 & $32-50$ & 57.3 & 8.2 & 34.5 & 1.61 & 2.64 & 5.4 & 18.6 & 10.4 & 8.2 \\
\hline Bt3 & $50-72$ & 48.5 & 11.4 & 42.5 & 1.62 & 2.58 & 4.2 & 21.2 & 12.8 & 8.4 \\
\hline $\mathrm{Cr}$ & $72+$ & \multicolumn{9}{|c|}{ Weathered Parent Material } \\
\hline \multicolumn{11}{|l|}{ P2 } \\
\hline Ap & $0-16$ & 84.5 & 5.5 & 8.5 & 1.48 & 2.61 & 16.5 & 4.2 & 2.5 & 1.7 \\
\hline Bt1 & $16-28$ & 70.5 & 8.5 & 21 & 1.52 & 2.65 & 10.2 & 12.6 & 6.2 & 6.4 \\
\hline Bt2 & $28-61$ & 60.5 & 9.5 & 30 & 1.52 & 2.62 & 6.5 & 16.5 & 9.1 & 7.4 \\
\hline $\mathrm{C}$ & $61+$ & \multicolumn{9}{|c|}{ Weathered Parent Material } \\
\hline \multicolumn{11}{|c|}{ 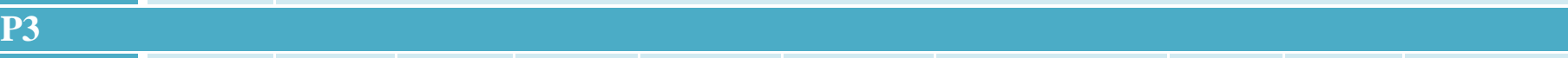 } \\
\hline Ap & $0-18$ & 21.5 & 26.5 & 52 & 1.76 & 2.61 & 1.45 & 30.4 & 20 & 10.4 \\
\hline $\mathbf{B A}$ & $18-36$ & 26.5 & 18.5 & 55 & 1.79 & 2.59 & 0.82 & 32.3 & 21.2 & 11.1 \\
\hline Bss1 & $36-69$ & 28.5 & 14.5 & 57 & 1.81 & 2.52 & 0.54 & 33.8 & 22.1 & 11.7 \\
\hline Bss2 & $69-97$ & 24.3 & 13.5 & 62.2 & 1.74 & 2.64 & 0.42 & 39.2 & 23.6 & 15.6 \\
\hline Bss3 & $\begin{array}{l}97- \\
130\end{array}$ & 21.5 & 19.3 & 59.2 & 1.85 & 2.63 & 0.21 & 36.5 & 20.8 & 15.7 \\
\hline \multicolumn{11}{|l|}{$\mathbf{P 4}$} \\
\hline Ap & $0-8$ & 83.2 & 6.5 & 10.3 & 1.54 & 2.63 & 18.21 & 6.1 & 3.6 & 2.5 \\
\hline $\mathbf{A 2}$ & 8-18 & 79.3 & 8.3 & 12.4 & 1.56 & 2.65 & 12.1 & 7.6 & 4.3 & 3.3 \\
\hline A3 & $18-29$ & 73.2 & 12.3 & 14.5 & 1.62 & 2.64 & 11.8 & 9.2 & 4.9 & 4.3 \\
\hline $\mathrm{Cr}$ & $29+$ & \multicolumn{9}{|c|}{ Weathered Parent Material } \\
\hline \multicolumn{11}{|l|}{ P5 } \\
\hline $\mathbf{A P}$ & $0-18$ & 73.2 & 9.4 & 17.4 & 1.45 & 2.64 & 12.8 & 9.8 & 5.5 & 4.3 \\
\hline Bt1 & $18-40$ & 64.3 & 8.9 & 26.8 & 1.47 & 2.61 & 8.6 & 15.4 & 8.2 & 7.2 \\
\hline Bt2 & $40-62$ & 61.5 & 10.2 & 28.3 & 1.51 & 2.63 & 5.4 & 17.1 & 8.7 & 8.4 \\
\hline $\mathbf{B t 3}$ & $\begin{array}{l}62- \\
82+\end{array}$ & 57.2 & 13.7 & 29.1 & 1.47 & 2.59 & 4.8 & 17.8 & 8.9 & 8.9 \\
\hline \multicolumn{11}{|l|}{ P6 } \\
\hline Ap & $0-16$ & 33.8 & 23 & 43.2 & 1.38 & 2.62 & 3.2 & 23.5 & 15.6 & 7.9 \\
\hline Bw1 & $16-45$ & 18.3 & 28.3 & 53.4 & 1.39 & 2.65 & 2.9 & 33.6 & 19 & 14.6 \\
\hline Bw2 & $45-72$ & 15.2 & 26.3 & 58.5 & 1.41 & 2.58 & 1.8 & 34.1 & 20.8 & 13.3 \\
\hline Bw3 & $\begin{array}{l}72- \\
105\end{array}$ & 15.8 & 24.3 & 59.9 & 1.52 & 2.65 & 1.5 & 36.1 & 22.1 & 14 \\
\hline
\end{tabular}


Table.4 Physico chemical properties of study area

\begin{tabular}{|c|c|c|c|c|c|c|c|c|c|c|c|c|}
\hline \multirow{2}{*}{$\begin{array}{l}\text { Pedon No. } \\
\text { \& Horizon }\end{array}$} & \multirow{2}{*}{$\begin{array}{l}\text { Depth } \\
(\mathrm{cm})\end{array}$} & \multirow{2}{*}{$\begin{array}{c}\text { pH } \\
(1: 2.5)\end{array}$} & \multirow{2}{*}{$\begin{array}{c}\mathrm{EC}(\mathrm{dS} \\
\left.\mathrm{m}^{-1}\right)\end{array}$} & \multirow{2}{*}{$\begin{array}{c}\text { Organic } \\
\text { carbon } \text { kg }^{-1}\end{array}$} & \multirow{2}{*}{$\begin{array}{c}\mathrm{CaCO}_{3} \\
(\%)\end{array}$} & \multirow{2}{*}{$\begin{array}{c}\text { CEC [c mol } \\
\left.(\mathrm{p}+) \mathrm{kg}^{1}{ }^{1}\right]\end{array}$} & \multicolumn{4}{|c|}{ Exchangeable bases [c mol (p+)kg- $\left.{ }^{1}\right]$} & \multirow[t]{2}{*}{$\operatorname{ESP}(\%)$} & \multirow{2}{*}{$\begin{array}{c}\text { Base Saturation } \\
(\%)\end{array}$} \\
\hline & & & & & & & $\mathrm{Ca}^{2+}$ & $\mathrm{Mg}^{2+}$ & $\mathrm{Na}^{+}$ & $\mathbf{K}^{+}$ & & \\
\hline \multicolumn{13}{|l|}{ Pedon 1} \\
\hline $\mathbf{A p}$ & $0-15$ & 6.3 & 0.15 & 0.28 & - & 6.2 & 2.3 & 1.1 & 0 & 0.3 & 0 & 59.68 \\
\hline Bt1 & $15-32$ & 6.7 & 0.13 & 0.35 & - & 11.5 & 5.9 & 2.1 & 0.2 & 0.3 & 1.74 & 73.91 \\
\hline Bt2 & $32-66$ & 6.9 & 0.12 & 0.31 & - & 16.5 & 9.2 & 3.5 & 0.5 & 0.3 & 3.03 & 81.82 \\
\hline Bt3 & $50-72$ & 7.3 & 0.16 & 0.28 & - & 21.2 & 10.5 & 5.7 & 0.6 & 0.2 & 2.83 & 80.19 \\
\hline $\mathrm{Cr}$ & $72+$ & \multicolumn{11}{|c|}{ Weathered granite gneiss } \\
\hline $\mathbf{A p}$ & $0-16$ & 7.5 & 0.16 & 0.48 & - & 4.8 & 2.3 & 1.1 & 0 & 0.3 & 0 & 77.08 \\
\hline Bt1 & $16-28$ & 7 & 0.34 & 0.4 & - & 10.4 & 4.4 & 1.9 & 0.3 & 1.8 & 2.88 & 80.77 \\
\hline Bt2 & $28-61$ & 6.9 & 0.13 & 0.29 & - & 11.6 & 4.9 & 2.1 & 0.6 & 1.9 & 5.17 & 81.9 \\
\hline $\mathbf{C}$ & $61+$ & \multicolumn{11}{|c|}{ Weathered Parent Material } \\
\hline \multicolumn{13}{|l|}{ Pedon 3} \\
\hline Ap & $0-18$ & 8.2 & 0.48 & 0.49 & 2.8 & 37.6 & 25.2 & 10.9 & 0.4 & 1.1 & 1.06 & 100 \\
\hline BA & $18-36$ & 8.3 & 0.53 & 0.36 & 3.2 & 39.1 & 26.2 & 10.8 & 0.9 & 1.2 & 2.3 & 100 \\
\hline Bss1 & $36-69$ & 8.5 & 0.61 & 0.34 & 7.9 & 41.8 & 27.6 & 10.5 & 2.3 & 1.4 & 5.5 & 100 \\
\hline Bss3 & $97-130$ & 8.6 & 0.16 & 0.38 & 6.8 & 49.4 & 30.2 & 13.3 & 4.1 & 1.8 & 8.3 & 100 \\
\hline \multicolumn{13}{|l|}{ Pedon 4} \\
\hline Ap & $0-8$ & 6.7 & 0.16 & 0.38 & - & 2.9 & 1.21 & 0.51 & 0.1 & 0.1 & 3.45 & 66.21 \\
\hline $\mathbf{A 2}$ & $8-18$ & 6.5 & 0.14 & 0.32 & - & 3.7 & 1.49 & 0.66 & 0.1 & 0.2 & 2.74 & 67.12 \\
\hline A3 & $18-29$ & 6.6 & 0.12 & 0.25 & - & 4.3 & 1.84 & 0.85 & 0.2 & 0.2 & 4.63 & 71.53 \\
\hline $\mathrm{Cr}$ & $29+$ & \multicolumn{11}{|c|}{ Weathered Parent Material } \\
\hline \multicolumn{13}{|l|}{ Pedon 5} \\
\hline $\mathbf{A p}$ & $0-18$ & 6.9 & 0.16 & 0.65 & - & 10.2 & 4.3 & 2.04 & 0.2 & 0.2 & 1.96 & 66.01 \\
\hline Bt1 & $18-40$ & 6.8 & 0.21 & 0.48 & - & 13.4 & 6.1 & 2.31 & 0.2 & 0.2 & 1.49 & 65.65 \\
\hline Bt2 & $40-62$ & 6.7 & 0.09 & 0.42 & - & 15.9 & 6.8 & 3.35 & 0.4 & 0.3 & 2.5 & 68.02 \\
\hline Bt3 & $62-82$ & 6.8 & 0.12 & 0.39 & - & 17.2 & 7.9 & 3.45 & 0.6 & 0.2 & 3.5 & 71.27 \\
\hline $\mathrm{Cr}$ & $82+$ & \multicolumn{11}{|c|}{ Weathered Parent Material } \\
\hline \multicolumn{13}{|l|}{ Pedon 6} \\
\hline Ap & $0-16$ & 8.8 & 0.15 & 0.72 & 9.8 & 28.5 & 18.1 & 8.5 & 0.3 & 0.9 & 1.05 & 97.54 \\
\hline Bw1 & $16-45$ & 8.7 & 0.14 & 0.44 & 10.1 & 34.8 & 22.8 & 10.1 & 0.5 & 1 & 1.44 & 98.85 \\
\hline Bw2 & $45-72$ & 8.6 & 0.42 & 0.32 & 12.2 & 36.5 & 24.3 & 10.2 & 0.6 & 1.1 & 1.64 & 99.18 \\
\hline
\end{tabular}


Table.6 Soil Nutrient Status of the Study Area

\begin{tabular}{|c|c|c|c|c|c|c|c|c|c|c|}
\hline \multirow{3}{*}{$\begin{array}{c}\text { Pedon No. \& } \\
\text { Horizon }\end{array}$} & \multirow[t]{3}{*}{ Depth (cm) } & \multicolumn{3}{|c|}{ Available macronutrients } & \multicolumn{4}{|c|}{ A vailable micronutrients } & \multirow[t]{3}{*}{$\mathrm{Ca} / \mathrm{Mg}$} & \multirow[t]{3}{*}{ CEC/Clay } \\
\hline & & $\mathbf{N}$ & $\mathbf{P}$ & $\mathbf{K}$ & Zn & $\mathrm{Cu}$ & $\mathbf{F e}$ & Mn & & \\
\hline & & \multicolumn{3}{|c|}{$\operatorname{kg~ha}^{-1}$} & \multicolumn{4}{|c|}{$\mathrm{mg} \mathrm{kg}^{-1}$} & & \\
\hline \multicolumn{11}{|l|}{ Pedon 1} \\
\hline Ap & $0-15$ & 275 & 18.5 & 300 & 0.42 & 0.45 & 7.60 & 18.60 & 2.09 & 0.59 \\
\hline Bt1 & $15-32$ & 252 & 16.5 & 280 & 0.46 & 0.42 & 6.40 & 17.20 & 2.81 & 0.51 \\
\hline Bt2 & $32-66$ & 232 & 12.5 & 195 & 0.39 & 0.38 & 5.80 & 12.70 & 2.63 & 0.48 \\
\hline Bt3 & $50-72$ & 205 & 10.5 & 156 & 0.28 & 0.32 & 5.40 & 12.50 & 1.84 & 0.50 \\
\hline $\mathrm{Cr}$ & $72+$ & \multicolumn{9}{|c|}{ Weathered Parent Material } \\
\hline \multicolumn{11}{|l|}{ Pedon 2} \\
\hline Ap & $0-16$ & 285 & 16.5 & 364 & 1.66 & 1.95 & 23.27 & 12.09 & 2.09 & 0.56 \\
\hline Bt1 & $16-28$ & 202 & 13.5 & 275 & 1.60 & 1.87 & 19.21 & 11.80 & 2.32 & 0.50 \\
\hline Bt2 & $28-61$ & 115 & 10.5 & 186 & 1.50 & 1.40 & 17.31 & 8.60 & 2.33 & 0.39 \\
\hline $\mathrm{C}$ & $61+$ & \multicolumn{9}{|c|}{ Weathered Parent Material } \\
\hline \multicolumn{11}{|l|}{ Pedon 3} \\
\hline Ap & $0-18$ & 265 & 19.5 & 364 & 0.49 & 1.28 & 5.80 & 9.65 & 2.31 & 0.72 \\
\hline $\mathbf{B A}$ & $18-36$ & 185 & 15.5 & 280 & 0.44 & 1.23 & 5.20 & 9.40 & 2.43 & 0.71 \\
\hline Bss1 & $36-69$ & 175 & 12.5 & 260 & 0.36 & 0.72 & 4.60 & 6.50 & 2.63 & 0.73 \\
\hline Bss2 & $69-97$ & 164 & 10.5 & 215 & 0.35 & 0.56 & 6.20 & 9.20 & 2.33 & 0.73 \\
\hline Bss3 & $97-130$ & 155 & 9.5 & 198 & 0.36 & 0.42 & 4.50 & 7.40 & 2.27 & 0.83 \\
\hline \multicolumn{11}{|l|}{ Pedon 4} \\
\hline Ap & $0-8$ & 208 & 19.0 & 235 & 0.95 & 0.46 & 6.78 & 5.35 & 2.37 & 0.28 \\
\hline $\mathbf{A 2}$ & $8-18$ & 195 & 12.5 & 145 & 0.75 & 0.39 & 7.15 & 4.87 & 2.26 & 0.29 \\
\hline $\mathbf{A 3}$ & $18-29$ & 175 & 10.1 & 109 & 0.87 & 0.54 & 10.06 & 5.45 & 2.16 & 0.30 \\
\hline $\mathrm{Cr}$ & $29+$ & \multicolumn{9}{|c|}{ Weathered Parent Material } \\
\hline \multicolumn{11}{|l|}{ Pedon 5} \\
\hline Ap & $0-18$ & 292 & 16.5 & 307 & 0.93 & 1.15 & 8.5 & 22.6 & 2.11 & 0.59 \\
\hline Bt1 & $18-40$ & 265 & 11.5 & 225 & 0.82 & 0.89 & 7.4 & 19.8 & 2.65 & 0.50 \\
\hline Bt2 & $40-62$ & 224 & 8.7 & 185 & 0.64 & 0.65 & 6.6 & 14.2 & 2.04 & 0.56 \\
\hline Bt3 & $62-82$ & 185 & 9.5 & 125 & 0.39 & 0.44 & 7.2 & 13.6 & 2.31 & 0.59 \\
\hline $\mathrm{Cr}$ & $82+$ & \multicolumn{9}{|c|}{ Weathered Parent Material } \\
\hline \multicolumn{11}{|l|}{ Pedon 6} \\
\hline Ap & $0-16$ & 278 & 19.5 & 330 & 0.65 & 0.49 & 6.40 & 14.20 & 2.13 & 0.66 \\
\hline Bw1 & $16-45$ & 165 & 25.6 & 245 & 0.60 & 0.41 & 11.6 & 25.6 & 2.26 & 0.65 \\
\hline Bw2 & $45-72$ & 155 & 13.5 & 215 & 0.49 & 0.86 & 10.4 & 24.2 & 2.38 & 0.62 \\
\hline Bw3 & $72-105$ & 145 & 8.5 & 185 & 0.39 & 0.72 & 8.2 & 15.6 & 2.57 & 0.67 \\
\hline
\end{tabular}


Table.5 Soil Classification of the study area

\begin{tabular}{|l|l|l|}
\hline Pedon 1 & $:$ & Fine, mixed, isohyperthermic Typic Rhodustalfs \\
\hline Pedon 2 & : & Fine-loamy, mixed, isohyperthermic, Typic Haplustalfis \\
\hline Pedon 3 & : & Fine, smectitic, isohyperthermic TypicHaplusterts \\
\hline Pedon 4 & : & Loamy-skeletal, mixed, isohyperthermic Lithic Ustorthents \\
\hline Pedon 5 & : & Fine loamy, mixed, isohyperthermic Typic Rhodustalfis \\
\hline Pedon 6 & $:$ & Fine, smectitic, isohyperthermic Vertic Haplustept \\
\hline
\end{tabular}

The detailed Physico-chemical properties of the study area of Eturnagaram division of Warangal district presented in table 4. The organic carbon content in study area was found to be low to medium and ranged from 0.28 to 0.72 per cent. The highest Organic carbon was recorded in AP horizon of pedon 6 and whereas the lowest Organic carbon was recorded in AP horizon of pedon 4. Organic carbon content in all the pedons showed a decreasing trend with depth. Almost all the pedons showed a decreasing trend in organic carbon with depth, which may be due to the fact that the surface horizons showed more organic matter content than sub-surface horizons due to the addition of plant residues and farm yard manure to surface horizons which resulted in higher organic carbon content in surface horizons than in the lower horizons. This observation was in accordance with results of Basavaraju et al., (2005) in soils of Chandragiri mandal in Chittoor district of Andhra Pradesh.

The $\mathrm{CaCO}_{3}$ content in soil under study area ranged from 2.8 to 12.2 per cent. The highest value of $\mathrm{CaCO}_{3}$ content was observed in the BW2 horizon of pedon 6 and whereas the lowest value of $\mathrm{CaCO}_{3}$ content was found in the horizon of AP pedon 2. Higher contents of $\mathrm{CaCO}_{3}$ observed in the lower horizons of most of the pedons might be due to high clay content which led to impeded leaching, consequently accumulation of $\mathrm{CaCO}_{3}$ in the lower horizons. Similar results were reported by Ramprakash and Seshagiri Rao (2002) in soils of Krishna district, Andhra Pradesh.

The CEC value of in the study area ranged from $4.8 \mathrm{C} \mathrm{mol}(\mathrm{p}+) \mathrm{Kg}^{-1}$ to $49.4 \mathrm{C} \mathrm{mol}(\mathrm{p}+)$ $\mathrm{Kg}^{-1}$ of soil. The highest CEC was observed in the horizon of $\mathrm{BSS}_{3}$ of pedon 3 and while the lowest CEC was found in the horizon of AP horizon of pedon 2. The higher CEC values observed throughout the soil depth in the pedons 1 was due to illuvial accumulation of clay and also because of dominance of smectite clay mineral. These findings were amply supported by the observations of Satish Kumar and Naidu (2012) and Leelavathi et al., (2010). Relatively low CEC is the reflection of parent material and higher degree of weathering leading to depletion of bases. Further, it may be due to dominance of clay minerals with low CEC especially illite and kaolinite. Similar findings were observed by Patil and Jagdish Prasad (2004) and Gangopadhyay et al., (2001).

The exchangeable bases in all the pedons found to be in the order of $\mathrm{Ca}^{+}>\mathrm{Mg}^{2+}>\mathrm{Na}^{+}>\mathrm{K}^{+}$on the exchangeable complex. The percent base saturation on the exchange complex of soil under investigated area varied from 59.68 per cent to 100 per cent. Comparatively exchangeable bases in the present study were more or less in the order of Vertisols > Inceptisols > Entisols. The basic cations content was low in Entisols which might be due to less clay and high 
silica content. Similar observations were earlier made by Sarkar et al., (2001) and Arun Kumar et al., (2002). Relatively higher exchangeable $\mathrm{Ca}$ was observed in surface horizons of some pedons which might be due to redistribution of $\mathrm{Ca}^{2+}$ by the vegetation.

These observations were in agreement with the findings of Patil and Jagdish Prasad (2004).

\section{Soil classification}

The detailed classification of the study area of eturnagaram division of Warangal district presented in table 5. Based on morphological, physical, physico-chemical, mineralogical and meteorological data, the soils in the study area of eturunagaram division of Warangal district were classified as Entisols, Alfisols, Inceptisols and Vertisols.

Whereas Pedon 4 do not have any diagnostic horizion and Presence of lithic contact within $50 \mathrm{~cm}$ of the mineral soil surface horizon were classified as Loamy-skeletal, mixed, isohyperthermic Lithic Ustorthents. Similarly, Mahapatra et al., (2000) classified soils of Kashmir region into orthents at sub-order level as they exhibited regular decrease in organic carbon.

Presence of argillic horizon and base saturation of more than $50 \%$ in all the subsurface layers Hue of 2.5 YR or redder and Value, moist, of 3 or less and Dry value no more than 1 unit higher than the moist value were classified as Fine, mixed, isohyperthermic Typic Rhodustalfs (pedon 1 and 5).

Absence of lithic contact within $100 \mathrm{~cm}$ of the mineral soil surface and Absence of calcic, halic, salic and sodic horizons hence, these pedons 3 were qualified to be placed under Fine, smectitic, isohyperthermic Typic
Haplusterts. Ramprakash and Seshagiri Rao (2002) and Ramprakash (2005) taxonomically classified some soils of Krishna district in Andhra Pradesh,

Presence of argillic horizon, base saturation of more than $50 \%$ in all the sub-surface layers due to the absence of Lithic contact, cracks within $125 \mathrm{~cm}$, lack of COLE value of more than 6.0, frigid temperatures, mesic or thermic soil temperatures, vertic properties, aquic conditions, saturation of water in any of the horizons for more than 20 days, pumice or pumice like fragments, entire lamille forms, $75 \%$ sand in the $75 \mathrm{~cm}$ argillic layer, calcic layer in the $100 \mathrm{~cm}$ depth of the pedon 2 was classified as Fine-loamy, mixed, isohyperthermic, Typic Haplustlafs.

Satyavathi and Suryanarayana Reddy (2004) and Ramprasad and Goverdhan (2011) classified the Alfisols of Telngana under Typic Rhodustlafs and Typic haplustalfs.

Pedons 6 had shown cracks within $125 \mathrm{~cm}$ of the mineral soil surface that are $5 \mathrm{~mm}$ or more wide through a thickness of $30 \mathrm{~cm}$ or more for some time in normal years and slicken-sides or wedge shaped aggegates in a layer $15 \mathrm{~cm}$ or more thick that has its upper within $125 \mathrm{~cm}$ of the mineral soil surface were classified as Fine, smectitic, isohyperthermic Vertic Haplustept.

The presence of cambic sub-surface diagnostic horizon $(\mathrm{Bw})$ in these pedon was recognized by the above features. Jagdish Prasad et al., (2001) reported that presence of cambic sub-surface horizon was the diagnostic criteria for Inceptisols.

Hence, all the above pedons were keyed out as Inceptisols at order level. Satyavathi and Suryanarayana Reddy (2003) classified some soils of Telangana into Inceptisols based on the presence of cambic horizon. 


\section{Nutrient status}

\section{Macronutrient status}

The nutrient status of the study area of eturnagaram division of Warangal district presented in table 6 . The available nitrogen in the soils under present investigation ranged from 115 to $292 \mathrm{~kg} / \mathrm{h}$. The lowest value of $115 \mathrm{~kg} \mathrm{ha}^{-1}$ soil was observed in Bt1 horizon of pedon 2. The highest value of $292 \mathrm{~kg} \mathrm{ha}^{-1}$ soil was noticed in AP horizon of pedon 6 . The available nitrogen was found to be maximum in the surface horizons and decreased more or less with depth of the pedons, which might be due to decreasing trend of organic carbon with depth. This observation was in agreement with the results of Sarkar et al., (2002) and Satish Kumar and Naidu (2012a).

The available phosphorus in soils of the study area varied from 8.5 to $25.6 \mathrm{~kg} \mathrm{ha}^{-1}$ soil. The lowest value of $8.5 \mathrm{~kg} \mathrm{ha}^{-1}$ soil was observed in $\mathrm{B}_{3}$ horizon of pedon 6 . The highest value of $25.6 \mathrm{~kg} \mathrm{ha}^{-1}$ soil was noticed in $\mathrm{BW}_{1}$ horizon of pedon 6. In general, higher available phosphorus was observed in the surface horizons and decreased regularly with depth. The reason for high available phosphorus in surface horizons might possibly be due to the confinement of crop cultivation to the rhizosphere which improves the organic carbon content in surface and supplementing the depleted phosphorus by external sources i.e., fertilizers and presence of small amounts of free iron oxide and exchangeable $\mathrm{Al}^{3+}$ in the surface horizons (Thangasamy et al., 2005).

The available potassium in soils of the study area ranged from 109 to $364 \mathrm{~kg} \mathrm{ha}^{-1}$ soil. The lowest value of $109 \mathrm{~kg} \mathrm{ha}^{-1}$ soil was observed in A3 horizon of pedon 4 and the highest value of $364 \mathrm{~kg} \mathrm{ha}^{-1}$ soil was noticed in AP horizon of pedon 2 and 3 respectively. Most of the pedons exhibited more or less a decreasing trend with depth.

Slow weathering and fixation of released potassium might have resulted in low exchangeable potassium status (Ramprakash and Seshagiri Rao, 2002). Amount and type of clay, organic carbon, soil $\mathrm{pH}$ and CEC significantly affects the K-availability in the soil. Similar observations were also noticed by Sharma and Anil Kumar (2003) a significant and positive correlation between clay content and available $\mathrm{K}$ as $\mathrm{K}$ availability was largely controlled by clay minerals.

\section{Micro nutrients}

The available zinc was ranged for 0.28 to 1.66 $\mathrm{mg} \mathrm{kg}^{-1}$ soil. The lowest value of $0.28 \mathrm{mg} \mathrm{kg}^{-1}$ soil was noticed in Bt horizon of pedon 1 and the highest value of $1.66 \mathrm{mg} \mathrm{kg}^{-1}$ of soil was recorded in AP horizon of pedon 2. The available copper in soils under study area ranged from 0.32 to $1.95 \mathrm{mg} \mathrm{kg}^{-1}$ soil. The lowest value of $0.32 \mathrm{mg} \mathrm{kg}^{-1}$ soil was observed in $\mathrm{Bt}_{2}$ horizon of pedon 1 and the highest value of $1.95 \mathrm{mg} \mathrm{kg}^{-1}$ of soil was noticed in AP horizon pedon 2. The available iron ranged from 4.50 to $23.27 \mathrm{mg} \mathrm{kg}^{-1}$ soil. The lowest value of $4.50 \mathrm{mg} \mathrm{kg}^{-1}$ soil was recorded in BSS3 horizon of pedon 3 and whereas the highest value of $23.21 \mathrm{mg} \mathrm{kg}^{-1}$ soil was noticed in AP horizon of pedon.2. The available manganese in soils of the study area of ranged from $4.87 \mathrm{mg} \mathrm{kg}^{-1}$ to $25.6 \mathrm{mg}$ $\mathrm{kg}^{-1}$ of soil. The lowest value of $4.87 \mathrm{mg} \mathrm{kg}^{-1}$ of soil was noticed in $\mathrm{A}_{2}$ horizon of pedon 4 and the highest value of $25.6 \mathrm{mg} \mathrm{kg}^{-1}$ soil was observed in $\mathrm{BW}_{1}$ horizon of pedon 6. The availability of these ions ( $\mathrm{Zn}, \mathrm{Cu}, \mathrm{Fe}$ and $\mathrm{Mn}$ ) increased with increase in organic matter because organic matter acts as a chelating agent for complexation of these micronutrients which reduces their adsorption, oxidation and precipitation into unavailable forms. Similar kind of 
relationship between $\mathrm{Zn}$ and organic carbon was also reported by Mahesh Kumar et al., (2011).

Based on morphological, physical and physico-chemical properties of eturunagaram division of warangal district were neutral to moderately alkaline, non-saline, low to medium in organic carbon and CEC. The exchangeable bases in all the pedons in the order of $\mathrm{Ca}^{2+}>\mathrm{Mg}^{2+}>\mathrm{Na}^{+}>\mathrm{K}^{+}$on the exchange complex. Whereas, the soils were low to medium in available nitrogen, low to high in available phosphorus and potassium. Available zinc was deficient to sufficient in all the horizon. The soils were sufficient in available iron, copper and manganese. The soils were classified as Typic Rhodustalfs, Typic Haplustalfs, Typic Haplusterts, Lithic Ustorthents and Vertic Haplustept at sub group level.

\section{References}

Arun Kumar, V., Natarajan, S and Sivasamy, R. 2002. Characterisation and classification of soils of lower PalarManimuthar watershed of Tamil Nadu. Agropedology. 12: 97-103.

Basava Raju, D, Naidu M V S, Ramavatharam N, Venkaiah K, Rama Rao G and Reddy K S 2005 Characterization, classification and evaluation of soils in Chandragiri mandal of Chittoor district, Andhra Pradesh. Agropedology 15: 55-62.

Leelavathi, G.P., Naidu, M.V.S., Ramavatharam, N and Karuna Sagar, G. 2009. Studies on genesis, classification and evaluation of soils for sustainable land use planning in Yerpedu mandal of Chittoor district, Andhra Pradesh. Journal of the Indian Society of Soil Science. 57: 109-120.

Mahesh Kumar, Singh, S.K., Raina, P and Sharma, B.K. 2011. Status of available major and micronutrients in arid soils of Churu district of western Rajasthan. Journal of the Indian Society of Soil Science. 59(2): 188-192.

Meena, R.H., Giri, J.D., Chaudhary, S.R and Shyampura, R.L. 2012. Characterization and classification of the soils of Malwa plateau in Banswara district of Rajasthan. Journal of Soils and Crops. 22(2): 216-225.

Nasre, R.A., Nagaraju, M.S.S., Rajeev Srivastava, Maji, A.K and Barthwal, A.K. 2013. Characterization, classification and evaluation of soils of Karanji watershed, Yavatmal district of Maharashtra for land resource management using geospatial technologies. Journal of the Indian Society of Soil Science. 61(4): 275-286.

Ram Prakash, T and Rao, S.M. 2002. Characterization and classification of some soils in a part of Krishna district, Andhra Pradesh. The Andhra Agricultural Journal. 49: 228-236.

Ramprasad, M. Govardhan V, Praveenrao, V., and Bhave, M. H. V. 2013. Characterization and classification of rice growing soils of central Telangana region of Andhra Pradesh. Journal of Research, ANGRAU 41(2) 52-58.

Satish Kumar, Y.S and Naidu, M.V.S. 2012a. Characteristics and classification of soils representing major landforms in Vadamalapeta mandal of Chittoor district, Andhra Pradesh. Journal of the Indian Society of Soil Science. 60(1): 63-67.

Satyavathi, P. L. A and Reddy M 2004. Soil site suitability for six major crops in Telangana region of Andhra Pradesh. Journal of the Indian Society of Soil Science. 52(3): 220-225.

Satyavathi, P.L.A and Suryanarayan Reddy, M. 2003. Characterization and classification of shallow, medium, deep red and black soils of Northern 
Telangana zone of AP. Journal of Tropical Agriculture. 41 (1\&2): 23-29.

Sharma, V. K and Anil Kumar 2003 Characterization and classification of the soil of upper Maul Khad catchment in wet temperate zone of Himachal Pradesh. Agropedology 13: 39-49.

Sharma, V. K., Sharma P. D, Sharma S P, Acharya C L and Sood R K 2004a Characterization of cultivated soils of Neogal watershed in North-West Himalayas and their suitability for major crops. Journal of the Indian Society of Soil Science. 52: 63-68. Ramavatharam N and Raghava Reddy C 2005 Characterization, classification and evaluation of soil resources in Sivagiri micro-watershed of Chittoor district in Andhra Pradesh for sustainable land use planning. Journal of the Indian Society of Soil Science. 53: $11-21$.

\section{How to cite this article:}

Narsaiah, E., T. Ramprakash, M. Chandinipatnaik, D. Vishnuvardhan Reddy and Bhupal Raj, G. 2018. Classification and Characterization of Soils of Eturunagaram Division of Warangal District in Telangana State. Int.J.Curr.Microbiol.App.Sci. 7(06): 582-594.

doi: https://doi.org/10.20546/ijcmas.2018.706.067 